Primljen / Received: 7.3.2016. Ispravljen / Corrected: 5.12.2016.

Prihvaćen / Accepted: 20.3.2017.

Dostupno online / Available online: 10.12.2017.

\section{Assessing safety of a railway stone arch bridge by experimental and numerical analyses}

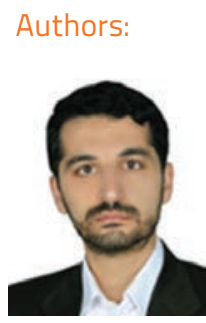

Assist.Prof. Shervan Ataei, PhD. CE Iran University of Science and Technology School of Railway Engineering

Teheran, Iran

Ataei@iust.ac.ir

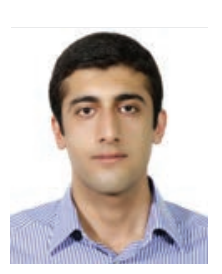

Amin Miri, MSc. CE

Iran University of Science and Technology School of Railway Engineering amin.miri.iust@gmail.com

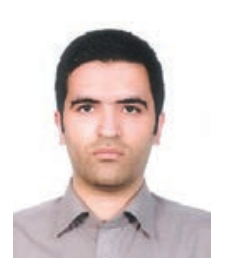

Meysam Jahangiri, MCE

Iran University of Science and Technology School of Railway Engineering m_jahangiri@rail.iust.ac.ir
Professional paper

Shervan Ataei, Amin Miri, Meysam Jahangiri

Assessing safety of a railway stone arch bridge by experimental and numerical analyses

Bridge response to predefined loading schemes is described and recorded by instrumenting the structure with deflectometers and accelerometers. Test results suggest that although vertical deflections of mid-spans are almost constant for all crossing speeds, the root mean square of acceleration values are positively correlated with the crossing speed. Field test results are then used to calibrate and verify the $3 \mathrm{D}$ finite element model of the bridge, and the latter is employed to assess behaviour of the structure at the serviceability limit state.

Key words:

masonry arch bridge, finite element model, serviceability limit state, ultimate limit state

Stručni rad

Shervan Ataei, Amin Miri, Meysam Jahangiri

Ocjena sigurnosti kamenog lučnog željezničkog mosta eksperimentalnim i numeričkim analizama

U radu je opisan odziv mosta na unaprijed definirana opterećenja, a određen je pomoću deflektometara i akcelerometara koji su u tu svrhu postavljeni na konstrukciju. Rezultati ispitivanja pokazuju da su vrijednosti korijena srednje kvadratne akceleracije pozitivno usklađene s brzinom prolaska, iako su vertikalni progibi na sredini raspona uglavnom konstantni pri svim brzinama prolaska. Rezultati dobiveni mjerenjima na terenu korišteni su za verifikaciju prostornog modela mosta, koji je korišten za ocjenu ponašanja konstrukcije pri graničnom stanju uporabivosti.

Ključne riječi:

lučni zidani most, model konačnih elemenata, granično stanje uporabivosti, granično stanje nosivosti

Fachbericht

Shervan Ataei, Amin Miri, Meysam Jahangiri

Bewertung der Sicherheit der gemauerten Eisenbahn-Bogenbrücke durch experimentelle und numerische Analysen

In der Arbeit wird die Reaktion der Brücke auf vordefinierte Belastungen beschrieben. Diese Reaktion wurde anhand von Deflektometern und Beschleunigungssensoren gemessen. Die Untersuchungsergebnisse zeigen, dass die Werte der Wurzel der mittleren quadratischen Beschleunigung mit der Durchgangsschnelligkeit positiv übereinstimmen, obwohl die vertikalen Verschiebungen in der Mitte der Breitspanne bei allen Durchgangsgeschwindigkeiten vorwiegend konstant sind. Die Messergebnisse vor Ort wurden für die Verifizierung eines Brückenraummodells verwendet, das für die Beurteilung des Verhaltens der Konstruktion beim Grenzzustand der Gebrauchstauglichkeit eingesetzt wurde.

Schlüsselwörter:

gemauerte Bogenbrücke, Methode der finiten Elemente, Grenzzustand der Gebrauchstauglichkeit, Grenzzustand der Tragfähigkeit 


\section{Introduction}

Masonry bridges comprise an important asset of many railway infrastructures. According to UIC, approximately 60 $\%$ of the bridge stock of railway organizations within UIC consists of masonry structures [1]. Many defects develop in masonry bridges due to their old age. Such defects range from material degradation to crack propagation and material loss. Degradation of masonry bridges is progressive and slow, but may be accelerated if remedial actions are not taken. Safety of masonry structures, therefore, is crucial to the safe operation of railway network. A catalogue of damage for masonry arch bridges and many NDT, SDT, and visual inspection methods, have been developed to enable examination of such structures [2-6], which allows for identification of different types of damage, possible causes and deterioration mechanisms.

There is also a growing demand for increasing throughput of the network by increasing axle loads or operational speed of trains. A major obstacle in doing so is the limited capacity of existing structures in the network, such as masonry bridges. In this respect, health monitoring and assessment of masonry bridges are crucial to the safe and economical operation of railways. The problem hindering evaluation of masonry bridge performance is the complexity of details and behaviour of such structures, which has been the subject of great debate during recent years.

A number of methods have been proposed for the evaluation of load carrying capacity of masonry bridges, including empirical methods such as MEXE [7], yield design based methods [8,9], fibre beam elements method [10], and those employing a scaled model of the bridge [11, 12].

Recently, several studies have successfully been used for assessing the load carrying capacity of masonry bridges by 2D and 3D finite elements models [13-19]. Caligyan et al. [17] conducted static and dynamic tests on a concrete arch bridge, and used the test results to calibrate a 3D model of the bridge. Marefat et al. [15] conducted static tests on a decommissioned masonry railway arch bridge. They concluded that despite initiation of cracks on the bridge structure, the bridge was capable of sustaining loads much higher than the service load. Brencich and Sabia [18] have conducted dynamic tests on a bridge with 18 spans of 10 meters. They used the test results to determine mode shapes and natural frequencies of the bridge and concluded that multiple spots on the bridge have to be instrumented in order to determine mode shapes of the bridge by dynamic tests.

UIC 778-3 [20] proposes a three stage assessment procedure, beginning by conservative assumptions and using the MEXE method. The second stage suggests using refined analysis and enhanced structural idealization. Material tests of the structure are also encouraged at this stage. Simplified two dimensional analysis models using elastic mechanism or equilibrium methods are proposed in the second stage. The last stage considers an exact model of the bridge, which may include dynamic testing of the bridge and analysis of exact material characteristics. Two and three dimensional analyses using finite or discrete models are employed at this stage.

This paper aims at presenting health monitoring and dynamic testing results obtained at the Mianeh Bridge, which is one of the oldest masonry arch bridges of the Iranian railway network. The bridge is studied in accordance with the threestage analysis procedure proposed by UIC-778-3. A 3D finite element model is developed using the Abaqus finite element software and calibrated to conform to test results. The numerical model is then used to assess bridge performance at the serviceability limit state. Three models are used to assess its performance at the ultimate limit state: a simple 2D model in Abaqus, a sophisticated 3D model in Abaqus, and $2 \mathrm{D}$ model in Ring. These three analyses are then compared and the results are reported. The research methodology is schematically presented in Figure 1.

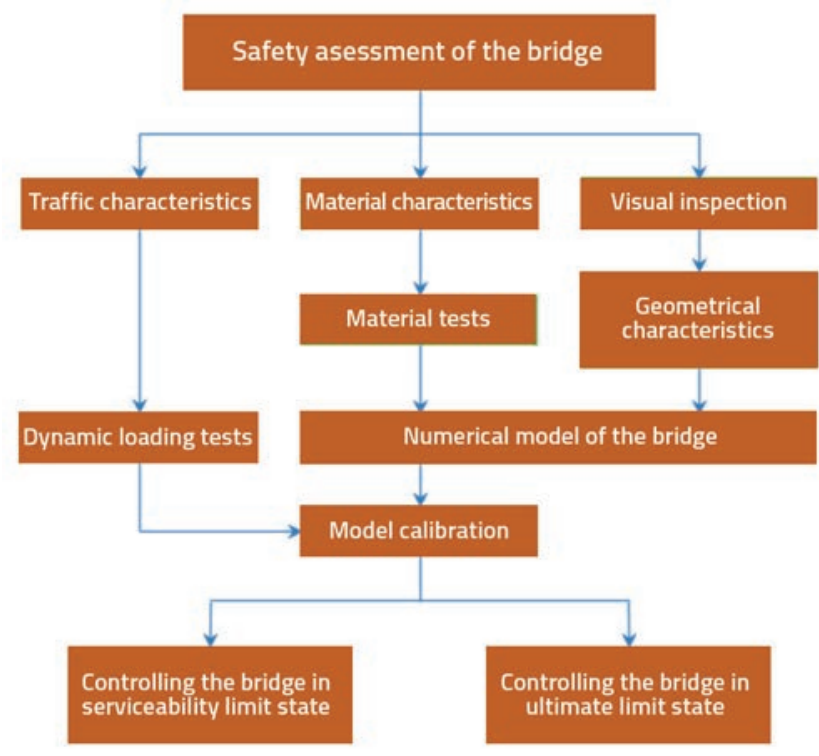

Figure 1. Schematic view of research methodology

\section{Bridge characteristics}

The Mianeh Bridge is a masonry arch bridge built more than 70 years ago in the north-western zone of the Iranian railway network, as shown in Figure 2.a. The bridge consists of $4 \times 25 \mathrm{~m}$ spans and $4 \times 8 \mathrm{~m}$ spans, and its overall length is 176 meters. The superstructure consists of U33 rails, steel sleepers, and rigid fasteners, and the ballast $35 \mathrm{~cm}$ in depth. The bridge carries a single track, with the $200 \mathrm{kN}$ allowable axle load and the maximum operating speed of $60 \mathrm{~km} / \mathrm{h}$. The span rise and length are presented in Figure 2.b. In order to test characteristics of the stone masonry, 9 cores were taken from various segments of the bridge and tested in the laboratory. The average compressive strength of $46 \mathrm{MPa}$ was obtained for 
stone masonry [21]. According to UIC 778-3, compressive strength properties of stone are determined as follows:

$f_{b}=K f_{m}=0,365 \cdot 46=16,79 \mathrm{MPa}$

gdje je:

$f_{b}$ - the characteristic strength of stone

$\mathrm{K}$ - the reduction factor (determined according to the number of tests)

$f_{m}$ - the average compressive strength.

Since nine samples were taken from the bridge, $K$ is 0.365 . Therefore, the characteristic compressive strength of the bridge is $16.79 \mathrm{MPa}$.

The bridge was visually inspected as a preliminary check. It had been repaired before and mortar loss has been compensated for. However, loss of mortar has been spotted in other segments of the bridge, as shown in Figure 3. Leachates are also visible at all spans, due to inadequate water drainage,

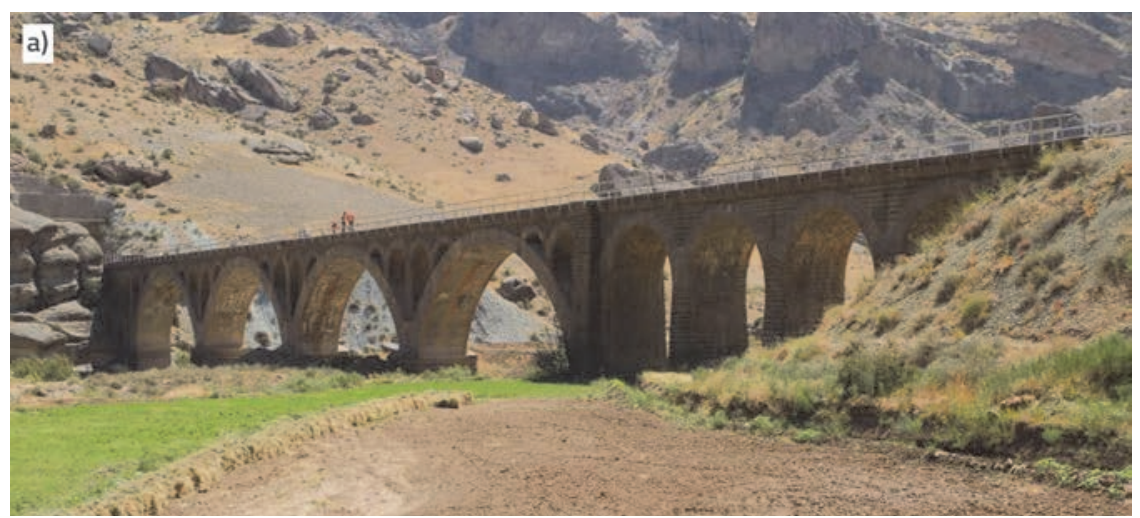

b)

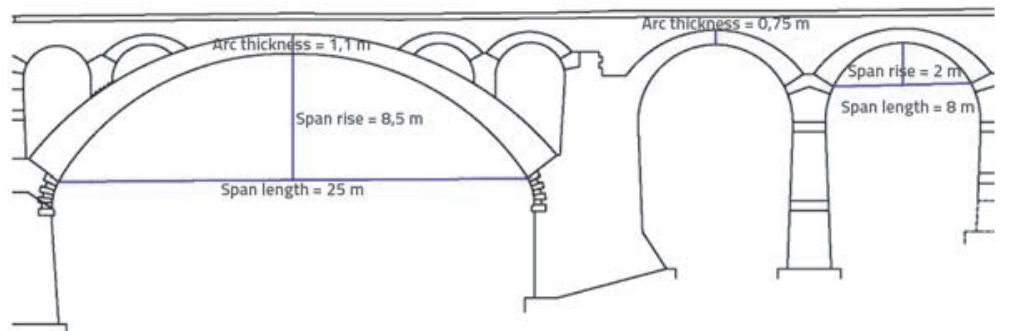

Figure 2. Mianeh Bridge: a) view of the bridge, b) schematic view of the bridge (span rise and length) as shown in Figure 4.a. Delamination and weathering of stones can also be spotted at some parts of the bridge, as presented in Figure 4.b. Although many segments of the bridge have been tested for material characteristics, this may not reflect the actual situation on the bridge. In fact, the existence of such defects, in addition to the age and deterioration of the masonry, has resulted in diverse characteristics of the material at different segments of the bridge. In this respect, dynamic testing could enable better understanding of the global response of the masonry.

\section{Test instrumentation}

The aim of field tests is to determine the Mianeh Bridge response to the passage of test train. For this purpose, vertical deflections and vibrations of four long $25 \mathrm{~m}$ spans were monitored. Since the Mianeh is of heritage value, all sensors were mounted on plastic frames glued to the bridge surface, and were later taken off.
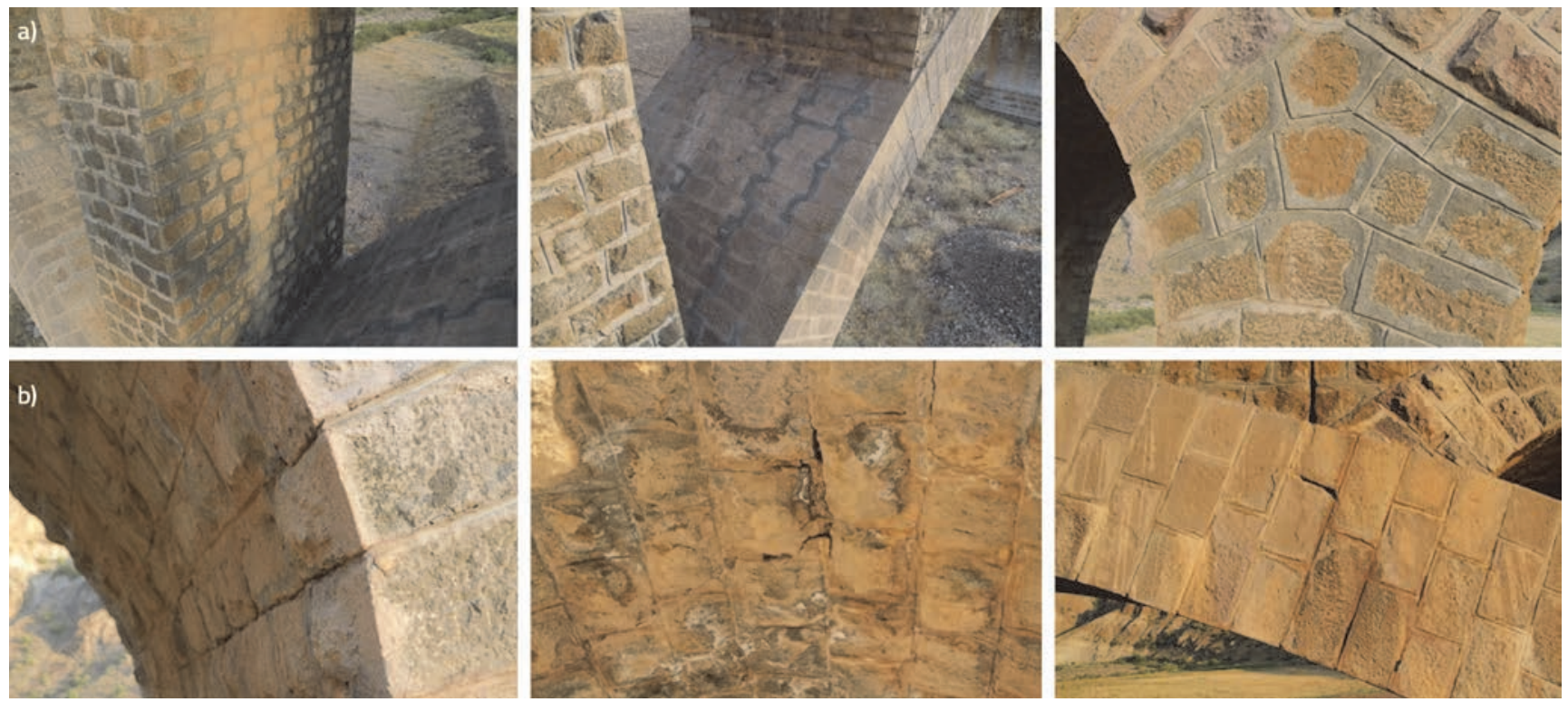

Figure 3. Mianeh Bridge: a) a view of the mended segments, b) a view of the spots with lost mortar defect 


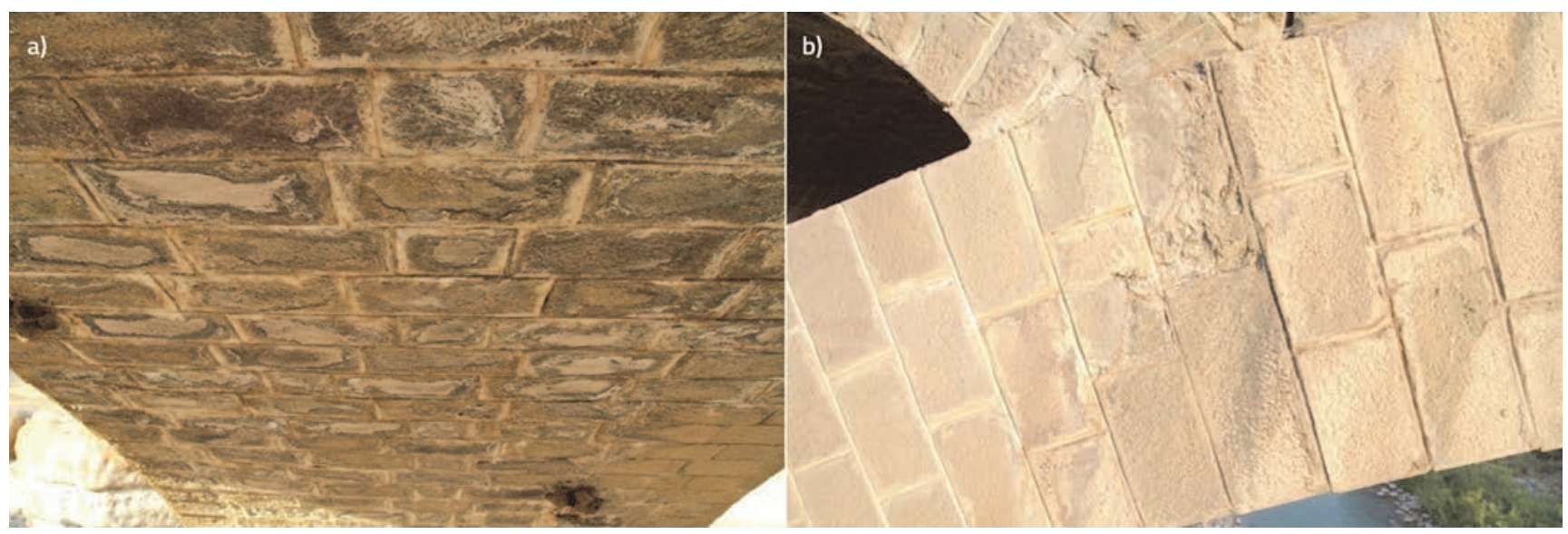

Figure 4. a) Delamination of stones and leachates, b) weathering of stones
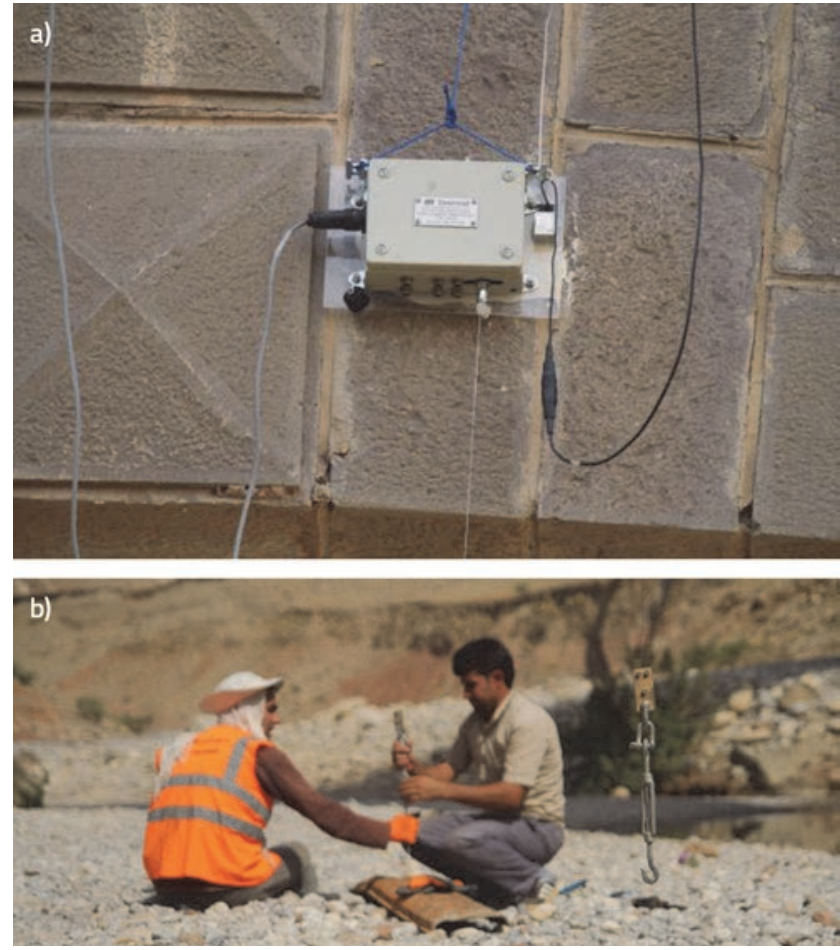

Figure 5. a) DCDT sensor mounted in the center of the span, b) DCDT cable fixed to the steel sleeper placed beneath the span

The arch deflection was to be recorded with the frequency and accuracy of at least $20 \mathrm{~Hz}$ and $100 \mu \mathrm{m}$, respectively. In order to record deflection of any spot on the bridge arches in accordance with such standards, a reference point was needed on which the deflection meter was fixed and any displacement relative to the fixed point was recorded. For this purpose, a deflection recording sensor called "Deflected Cantilever Displacement Transducer", or simply "DCDT", was used. The deflection of cantilever relative to a fixed point was determined by measuring tensions of a pulled cantilever. The DCDT sensor is capable of recording the displacement in a range of $25 \mathrm{~mm}$ with an accuracy of $10 \mu \mathrm{m}$. In order to use DCDT sensors, a cable was fixed to a heavy weight located beneath the bridge span, which acted as the reference point of the sensor. A view of the installed DCDT is given in Figure 5.

To determine the exact speed and location of test train on the bridge, a series of LVDT sensors and strain gauges were mounted on the rail, as shown in Figures 6 and 7. Furthermore, bridge vibrations due to test train load were recorded by seven piezo-resistive accelerometers with a capacity of $2 \mathrm{~g}$. Overall, 15 sensors were mounted on the Mianeh Bridge as depicted in Figure 8. The data were recorded with a frequency of $2 \mathrm{KHz}$ throughout the tests.

Three 6-axle locomotives and five 4-axle freight wagons were used to form the test train. Four different train formations were considered throughout the tests: full train consisted of 3 locomotives and 5 freight wagons (TF1), three locomotives (TF2), two locomotives (TF3), and a single locomotive (TF4). Axle spacing and loads are schematically presented in Figure 10. Dynamic tests were repeated for each train formation with speeds ranging from 5 to $75 \mathrm{~km} / \mathrm{h}$. A total of 36 dynamic tests were conducted.

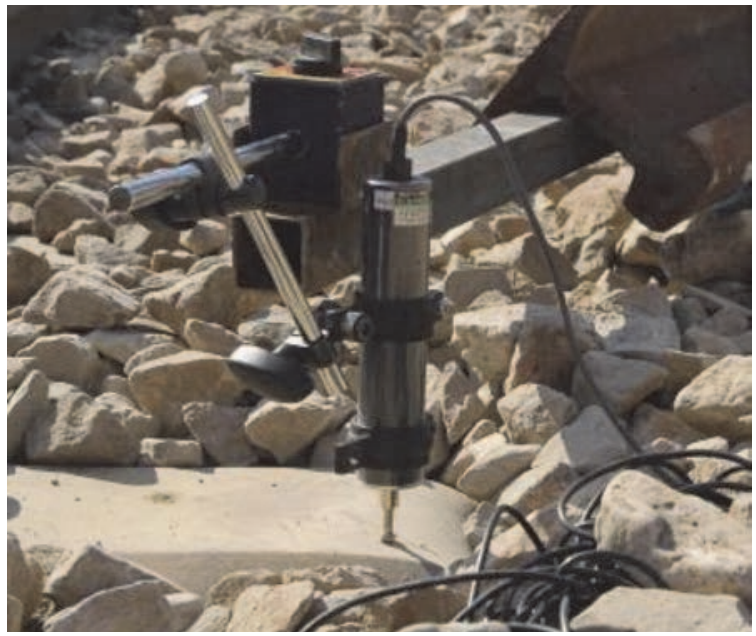

Figure 6. LVDT mounted on sleeper to determine the exact speed and location of test train axles 


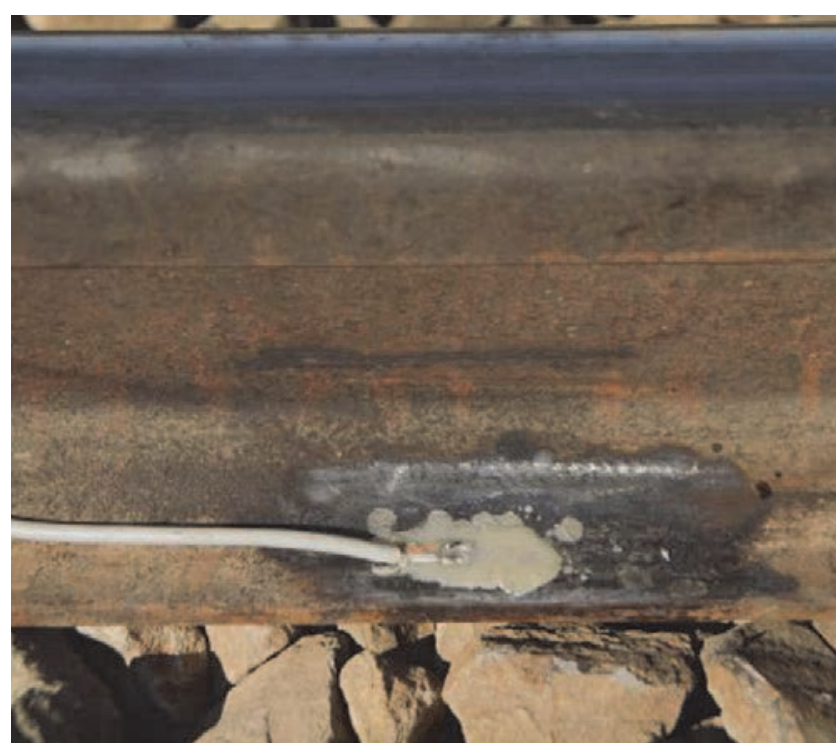

Figure 7. Strain gauge mounted on rail heel to determine the exact speed and location of test train axles

\section{Field test results}

The calculated assessment presumes that together with the geometry, foundations and loads, all essential material properties and their status are known or can be estimated, and that the load transfer can be described realistically in mathematical terms [20].

In reality, however, it is fairly difficult to determine exact material properties of the whole material used in masonry bridges. There are sometimes ambiguities in the structure of such bridges as well. In such cases, field tests are a useful way of determining the overall behaviour of the bridge, due to the use of predefined loading schemes.

The bridge response in terms of vertical deflection at the centre of the third span at both northern and southern sides is presented in Figure 10. Since no superelevation exists on bridge superstructure, DCDT signatures on both sides are almost identical. The maximum recorded deflection of all spans, due to the passage of test train TF1 at varying speeds, is presented in Figure 11. According to figure 11, the third span has the
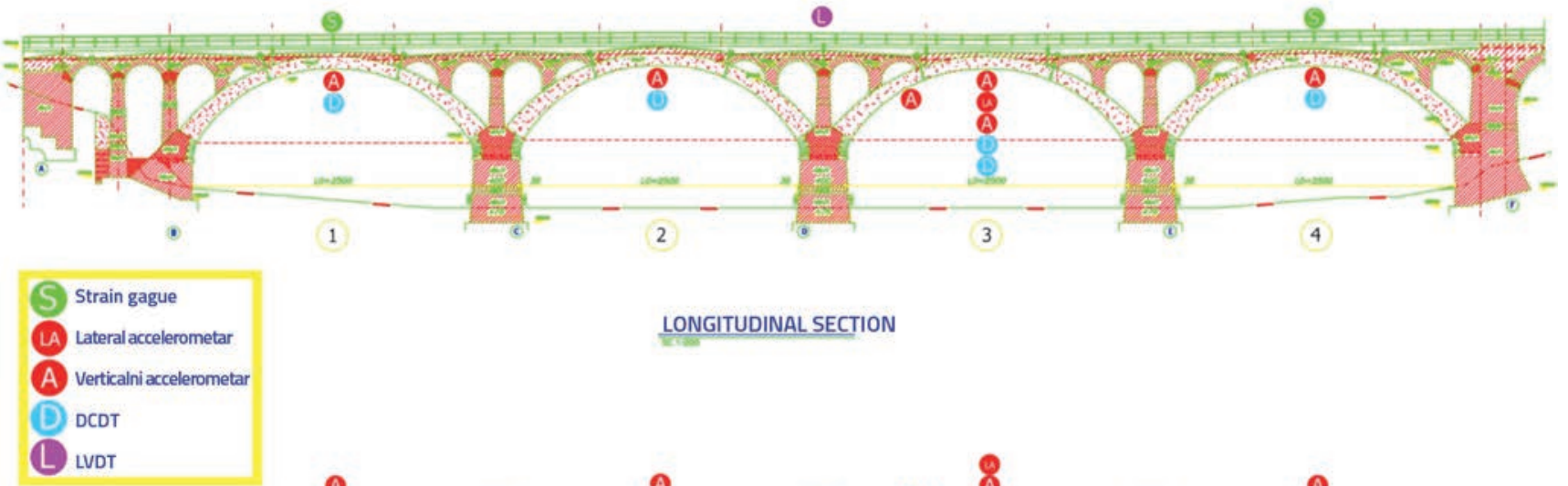

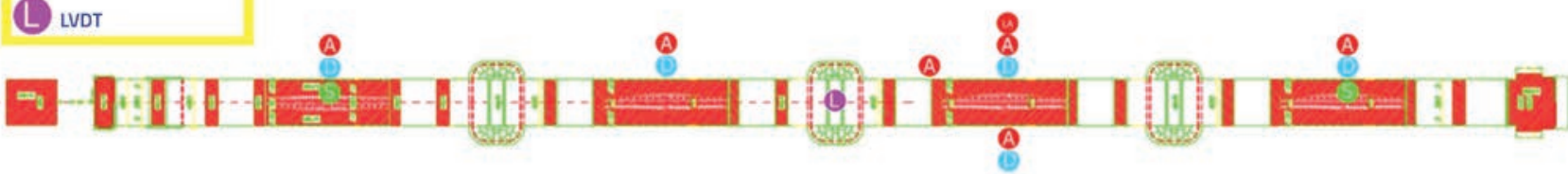

DECK PLAN

Figure 8. Test instrumentation and span indexing of Mianeh Bridge
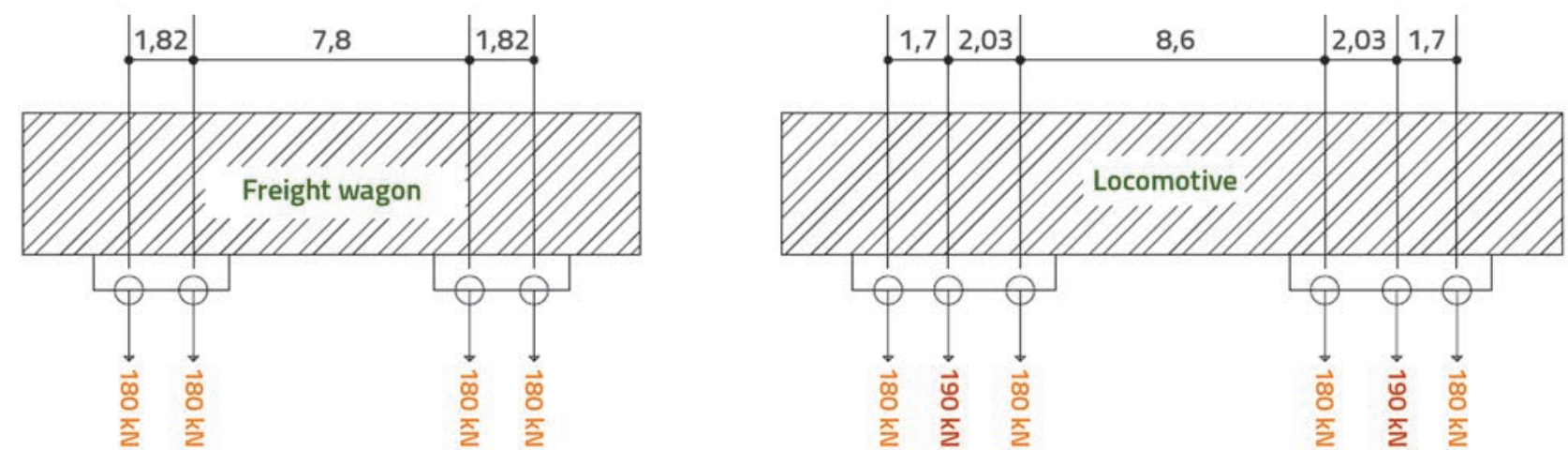

Figure 9. Schematic plan of test train axles 
highest deflection level compared to other monitored spans. At this span the deflection is on an average by $20 \%$ higher than at other spans. The root mean square of recorded acceleration signatures was calculated in order to compare vibration levels at different spots of the bridge, as presented in Figure 12. This figure suggests that there is a positive correlation between RMS of acceleration signatures of all spans and speed of test train. Figure 13 presents the recorded RMS of vertical acceleration in the centre of the third span, for different loading schemes. The RMS of acceleration due to the loading scheme of TF1 is slightly higher than other loading schemes, while TF4 results in the lowest level of RMS of acceleration.

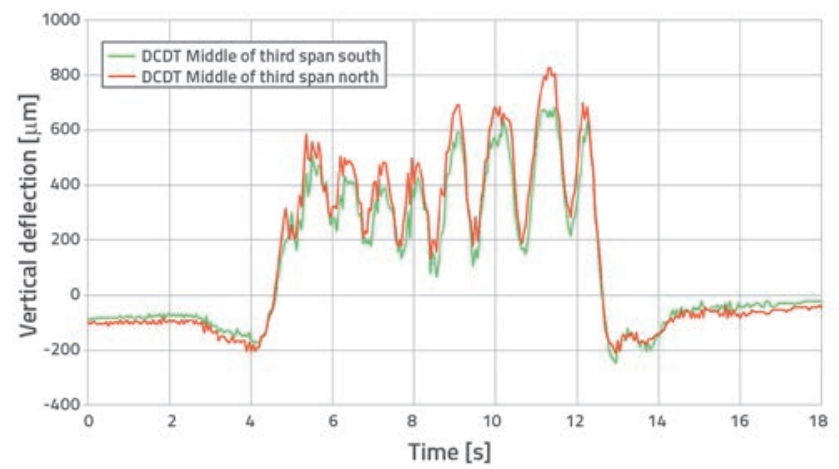

Figure 10. Vertical deflection signature of northern and southern sides of the third span centre, due to passage of TF1 at the speed of $63 \mathrm{~km} / \mathrm{h}$

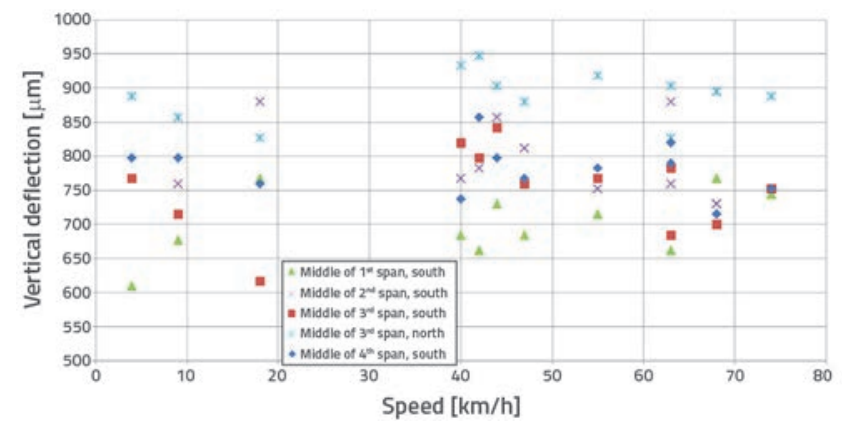

Figure 11. Maximum recorded vertical deflection signatures of all spans, due to passage of test train TF1 at varying speeds

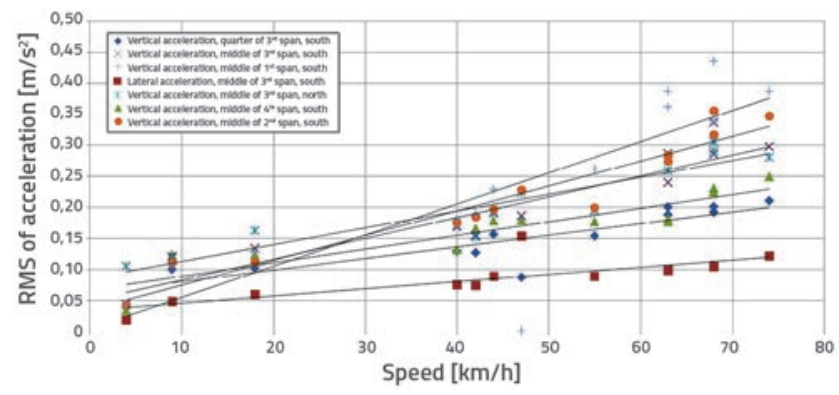

Figure 12. RMS of recorded accelerations in all spans of the Mianeh Bridge, due to passage of test train TF1 at varying speeds

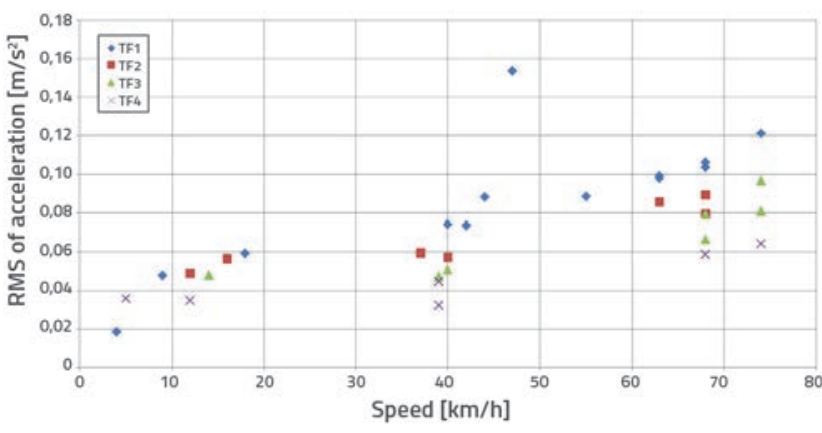

Figure 13. RMS of acceleration in the middle of third span of Mianeh bridge, due to different loading schemes $\left[\mathrm{m} / \mathrm{s}^{2}\right]$

\section{Numerical model of Mianeh Bridge}

A 3D finite element model of the Mianeh Bridge was developed in Abaqus software to study the possibility of increasing the allowable axle load and assessing safety at the Mianeh Bridge, as shown in Figure 14. Hexagonal elements were used to develop the model, which involved a total of 84800 elements. All geometrical and structural characteristics of the bridge were considered, which included joints and filling material. Connection between piers and foundations were modelled as fixed joints. In order to set material characteristics of the model, an initial equivalent modulus of elasticity was determined using equations specified in UIC 778-3 [20]. The following could be used for ashlar masonry and cement mortar:

$E=5000+300 f_{b}$

where:

$\mathrm{E}$ - the equivalent elastic modulus of the masonry.

The characteristic compressive strength of stone, as determined in Section 2, amounts to $16.79 \mathrm{MPa}$. Hence, an initial modulus of elasticity of $10.04 \mathrm{GPa}$ was determined for the masonry. The finite element model of the bridge was calibrated to minimize the differences between the analytically and experimentally estimated modal properties by changing some uncertain modelling parameters, such as material properties and boundary conditions. The modulus of elasticity was used as the calibration parameter for each span, and was modified to make sure that the numerical model conforms to the response of the Mianeh Bridge in terms of vertical deflection and natural frequencies as recorded during field tests, as shown in Figure 15. The calibrated modulus of elasticity of masonry was determined, as presented in Table 1. It is also possible to determine the compressive strength of masonry based on the calibrated modulus of elasticity for each span. To do so, the following equation from the Eurocode standard is employed [21]:

$f_{k}=\frac{E}{K_{E}}$

The corresponding results are presented in Table $1 . \mathrm{K}_{\mathrm{E}}$ is set to 1000. 
Table 1. Initial and calibrated elasticity modulus, and compressive strength of modelled material

\begin{tabular}{|c|c|c|c|}
\hline Span ID & $\begin{array}{c}\text { Initial elasticity modules } \\
{[\mathrm{GPa}]}\end{array}$ & $\begin{array}{c}\text { Initial compressive } \\
\text { strength } \\
{[\mathrm{MPa}]}\end{array}$ & $\begin{array}{c}\text { Calibrated elasticity } \\
\text { modules } \\
{[\mathrm{GPa}]}\end{array}$ \\
\hline $1^{\text {st }}$ & 10.04 & 10.04 & 7.30 \\
\hline $2^{\text {nd }}$ & 10.04 & 10.04 & 6.90 \\
\hline $3^{\text {rd }}$ & 10.04 & 10.04 & 6.70 \\
\hline $4^{\text {th }}$ & 10.04 & 10.04 & 7.90 \\
\hline strength & 7.20 \\
\hline Rest of the spans & 10.04 & 10.04 & 7.20 \\
\hline
\end{tabular}

Table 2. Natural frequencies of the Mianeh Bridge derived from numerical model and field tests [Hz]

\begin{tabular}{|c|c|c|c|c|c|c|c|}
\hline Mode shape & First & Second & Third & Fourth & Fifth & Sixth & Seventh \\
\hline \multirow{2}{*}{ Field test $[\mathrm{Hz}]$} & 2.73 & 3.51 & 3.97 & 4.81 & 6.77 & 7.1 & 7.74 \\
\hline & Lateral & Lateral & Vertical & Lateral & Vertical & Lateral & Lateral \\
\hline \multirow{2}{*}{ Finite element model $[\mathrm{Hz}]$} & 2.99 & 3.23 & 3.65 & 3.99 & 5.37 & 5.44 & 6.32 \\
\hline & Lateral & Lateral & Lateral & Lateral & Vertical & Lateral & Lateral \\
\hline
\end{tabular}

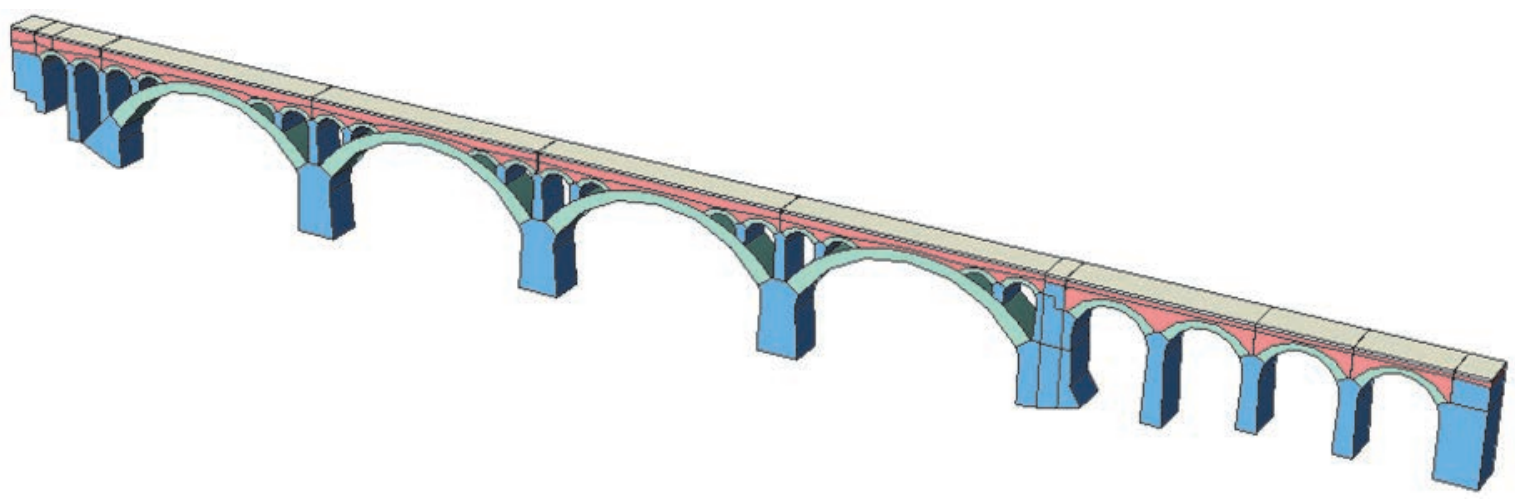

Figure 14. 3D finite element model of the Mianeh Bridge developed in Abaqus

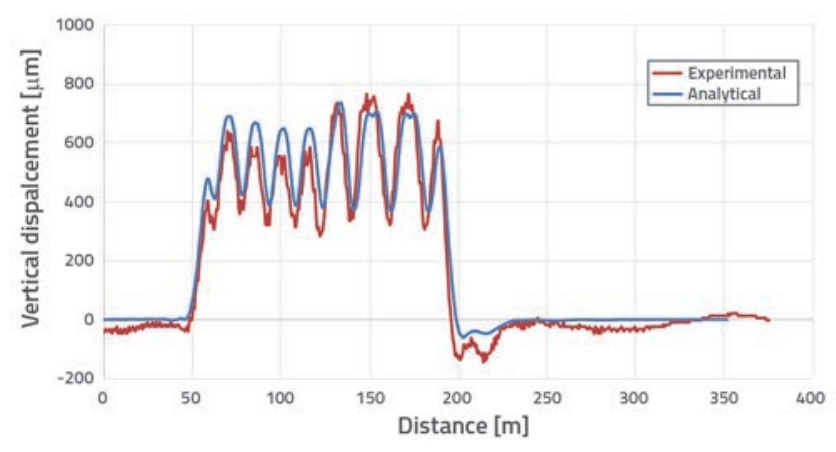

Figure 15. Calibration of numerical model of the Mianeh Bridge using test results (vertical deflection at centre of the $4^{\text {th }}$ span, due to the passage of two locomotives and 5 wagons at the speed of $50 \mathrm{~km} / \mathrm{h}$ )

Natural frequencies and modal shapes of the bridge are presented in Table 2 and Figure 16. They were calculated using the calibrated numerical model. Free vibration segments of acceleration signatures, also shown in Table 2, were considered in calculating natural frequencies of field test results. According to UIC 778-3, the difference between the measured and calculated frequencies of the $1^{\text {st }}$ and $2^{\text {nd }}$ modes shall have an insignificant difference of $15 \%$ and $25 \%$, respectively. According to Table 2, the difference between the measured and calculated natural frequencies of the first and second mode shapes is less than $10 \%$.

\section{Assessment of stresses at serviceability limit state}

According to BD 91/04 [23], the permissible compression stresses due to the loading scheme of $\mathrm{D}+1.2 \mathrm{~L}$ at serviceability limit state shall not exceed $0.4 \mathrm{f}_{\mathrm{k}}$. The BD91/04 standard also mandates that the eccentricity of the centre of compression in arch ring (which is designated with letter "e") shall not exceed $0.25 h$, where " $h$ " is the overall thickness of the arch. Service loads considered in analysis are typical traffic trains of the region (including TF1 and TF2) and the loading scheme proposed in EN 1991-2 [24] (LM71) with an axle load of 25 tons, as presented in Figure 17. The impact factor, according to EN 1991-2 is determined as follows: 

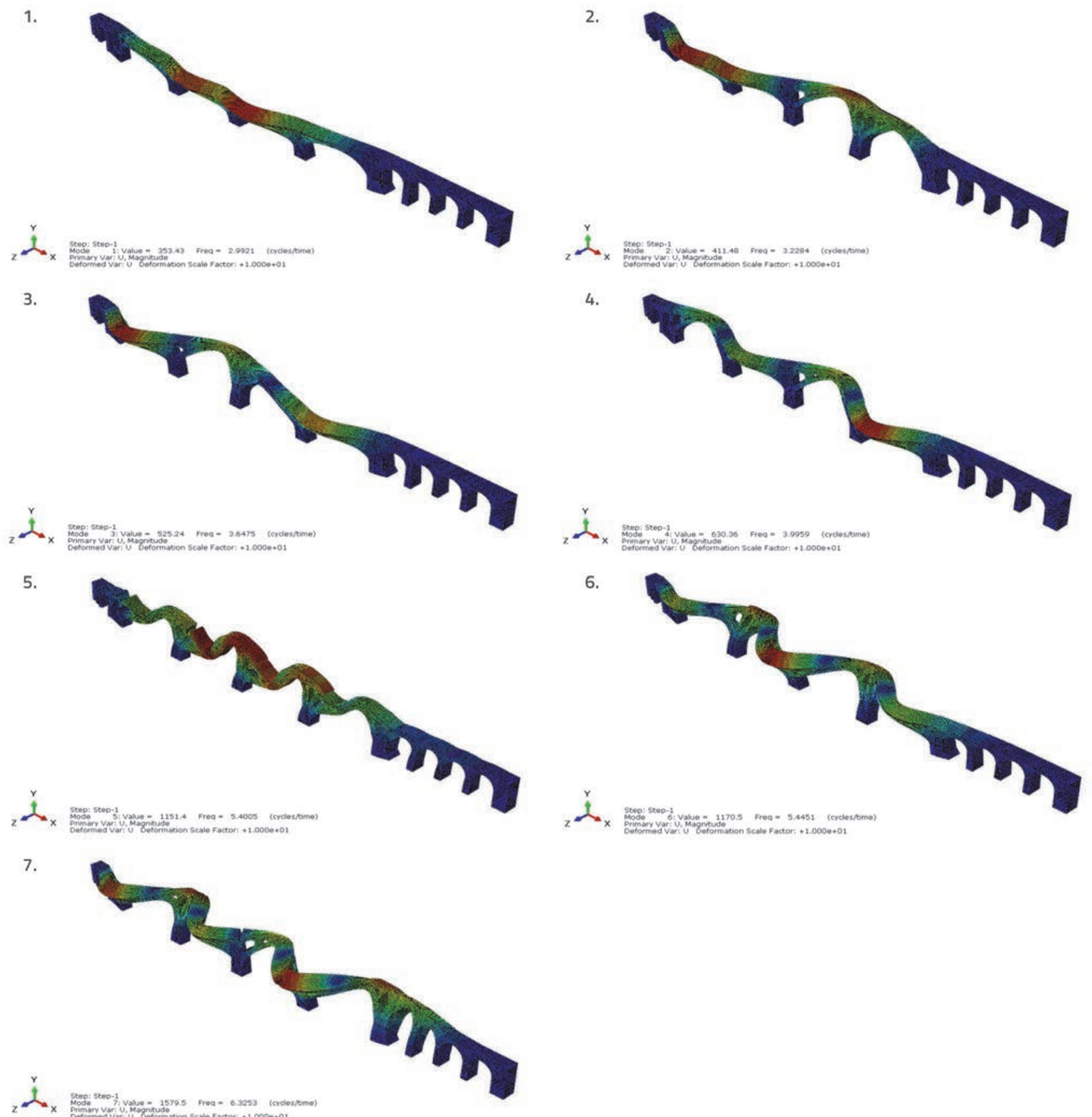

Figure 16. First seven mode shapes of the Mianeh Bridge derived by numerical model of the bridge

$\Phi_{z}=\frac{2,16}{\sqrt{L_{\phi}}-0,2}+0,73$

where:

$\Phi_{z}$ - the impact factor for track with standard maintenance $L_{\phi}$ - half of the span length.

The impact factors for $25 \mathrm{~m}$ and $8 \mathrm{~m}$ spans are 1.38 and 1.93, respectively.
Stresses at the middle and quarter points of the first five spans of the Mianeh Bridge, calculated as LM71, TF1, and TF2, were applied to the bridge, as presented in Table 3, along with permissible values. Positive values correspond to tensional stresses, while negative values indicate compression stresses. As expected, the stresses and eccentricity of the centre of compression due to application of LM71 are higher compared to those of TF1 and TF2. Table 3 suggests that compressive stresses are all within allowable thresholds, while eccentricity 
Table 3. Stresses and eccentricity of centre of compression at different spots of the Mianeh Bridge, due to application of TF1, TF2, and LM71 (values marked in red exceed the allowable limits)

\begin{tabular}{|c|c|c|c|c|c|c|c|c|c|c|c|c|c|}
\hline \multirow{3}{*}{ Span } & \multirow{3}{*}{\multicolumn{2}{|c|}{ Position }} & \multicolumn{4}{|c|}{$\mathbf{S}[\mathrm{MPa}]$} & \multirow{3}{*}{$\begin{array}{c}\mathbf{h} \\
{[\mathrm{mm}]}\end{array}$} & \multirow{2}{*}{\multicolumn{3}{|c|}{ e $[\mathrm{mm}]$}} & \multirow{2}{*}{\multicolumn{3}{|c|}{ e/h }} \\
\hline & & & \multirow{2}{*}{$\begin{array}{c}\text { Allowable } \\
(0,4 \mathrm{fk})\end{array}$} & \multicolumn{3}{|c|}{ Exerted } & & & & & & & \\
\hline & & & & TF1 & TF2 & LM71 & & TF1 & TF2 & LM71 & TF1 & TF2 & LM71 \\
\hline \multirow{4}{*}{$1^{\text {st }} \operatorname{span}$} & \multirow{2}{*}{$\begin{array}{l}\text { Middle } \\
\text { span }\end{array}$} & Top Fiber & -2.92 & -0.89 & -0.90 & -1.35 & \multirow{2}{*}{1100} & \multirow{2}{*}{213.78} & \multirow{2}{*}{206.11} & \multirow{2}{*}{288.30} & \multirow{2}{*}{0.19} & \multirow{2}{*}{0.19} & \multirow{2}{*}{0.26} \\
\hline & & Bot. Fiber & -2.92 & 0.07 & 0.05 & 0.30 & & & & & & & \\
\hline & \multirow{2}{*}{$\begin{array}{c}\text { Quarter } \\
\text { span }\end{array}$} & Top Fiber & -2.92 & -0.47 & -0.47 & -0.80 & \multirow{2}{*}{1350} & \multirow{2}{*}{72.65} & \multirow{2}{*}{72.57} & \multirow{2}{*}{48.12} & \multirow{2}{*}{0.05} & \multirow{2}{*}{0.05} & \multirow{2}{*}{0.04} \\
\hline & & Bot. Fiber & -2.92 & -0.91 & -0.91 & -1.24 & & & & & & & \\
\hline \multirow{3}{*}{$\begin{array}{l}2^{\text {nd }} \\
\text { span }\end{array}$} & $\begin{array}{l}\text { Middle } \\
\text { span }\end{array}$ & Bot. Fiber & -2.76 & 0.15 & 0.15 & 0.46 & 1100 & 254.32 & 250.12 & 351.19 & 0.23 & 0.23 & 0.32 \\
\hline & Quarter & Top Fiber & -2.76 & -0.54 & -0.54 & -0.90 & & & & & & & \\
\hline & span & Bot. Fiber & -2.76 & -0.86 & -0.86 & -1.25 & 1350 & 50.77 & 50.96 & 36.37 & 0.04 & 0.04 & 0.03 \\
\hline & Middle & Top Fiber & -2.68 & -0.93 & -0.93 & -1.32 & & & & & & & \\
\hline $3^{\text {rd }}$ & span & Bot. Fiber & -2.68 & 0.08 & 0.08 & 0.32 & 1100 & $216.5 /$ & 215.84 & 302.80 & 0.20 & 0.20 & 0.28 \\
\hline span & Quarter & Top Fiber & -2.68 & -0.54 & -0.55 & -0.85 & 1350 & 53.27 & 5389 & 3937 & 004 & 004 & 003 \\
\hline & Middle & Top Fiber & -2.88 & -0.91 & -0.92 & -1.39 & & & & & & & \\
\hline $4^{\text {th }}$ & span & Bot. Fiber & -2.88 & 0.20 & 0.20 & 0.46 & 1100 & 285.49 & 284.37 & 365.12 & 0.26 & 0.26 & 0.33 \\
\hline span & Quarter & Top Fiber & -2.88 & -0.51 & -0.52 & -0.86 & & & & & & & \\
\hline & span & Bot,Fiber & -2.88 & -0.89 & -0.89 & -1.26 & 1350 & 60.12 & 59.46 & 42.34 & 0.04 & 0.04 & 0.03 \\
\hline & Middle & Top Fiber & -2.88 & -0.36 & -0.36 & -0.26 & 750 & 41908 & 14607 & 78874 & 056 & 060 & 105 \\
\hline $5.5 p a n$ & span & Bot. Fiber & -2.88 & 0.19 & 0.20 & 0.36 & 150 & 419.08 & 446.91 & $188 . / 4$ & 0.56 & 0.60 & 1.05 \\
\hline 5.spdil & Quarter & Top Fiber & -2.88 & -0.22 & -0.23 & -0.20 & 800 & 587 & 711 & 34 & 01 & 101 & 004 \\
\hline & span & Bot. Fiber & -2.88 & -0.25 & -0.25 & -0.34 & 000 & 3.01 & 1.11 & 35.54 & 0.01 & 0.01 & 0.04 \\
\hline
\end{tabular}

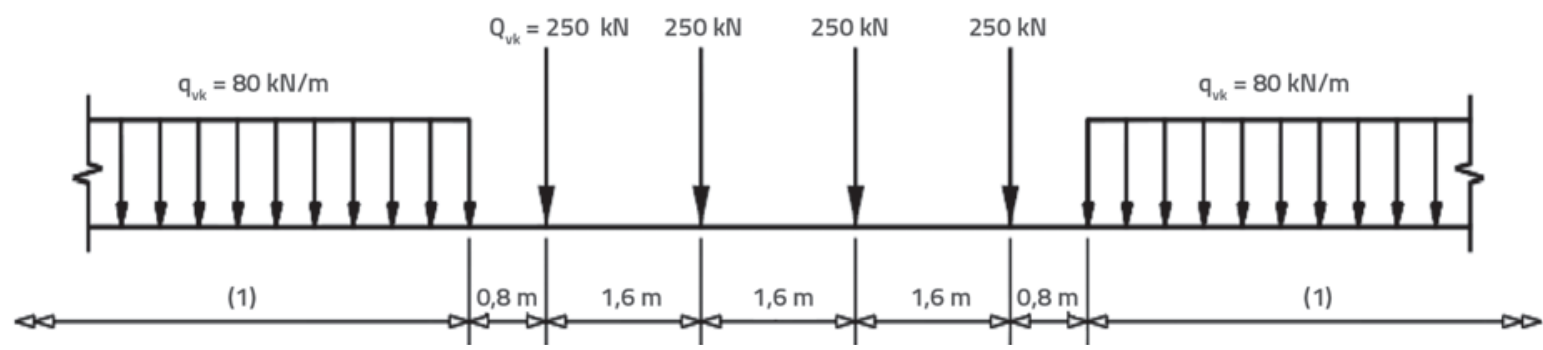

Figure 17. Proposed loading scheme of EN 1991-2-2:2003, with an axle load of 250 kN (Load Model - LM71)

of the centre of compression is an issue in all spans except in the first span. It can be noted that the eccentricity of the centre of compression in middle spans exceeds the allowable threshold, and that it is extremely higher in the $8 \mathrm{~m}$ span compared to 25 m spans.

\section{Assessment of bridge behaviour at ultimate limit state}

The ultimate load-carrying capacity (ULC) is expressed in terms of a load factor, which is the ratio between the collapse load and live load. According to UIC 778-3 (second edition), the MEXE method is to be employed for assessment of masonry arch bridges at ultimate limit state, since the 4-hinge mechanism is the most probable mode of failure in single-ring arches [25]. On the other hand, BD91-04 proposes the following equation for assessing ULC of masonry arch bridges, in which " $p$ " is the compressive force in the arch ring due to ultimate design load effects, "b" is the width of the arch ring under consideration, and the rest of the parameters are as defined before. Bridge assessment at ULS is carried out in accordance with both standards to enable comparison of results.

$$
P \leq 0,4 b f_{k}(\mathrm{~h}-2 e)
$$

The MEXE method can not be used for the Mianeh Bridge since geometrical characteristics of both $8 \mathrm{~m}$ and $25 \mathrm{~m}$ spans exceed allowable thresholds of the MEXE method. In the MEXE method, the span length cannot exceed 20 meters (it is therefore not suitable for $25 \mathrm{~m}$ spans). Also, no value is given for $8 \mathrm{~m}$ spans, if the corresponding arch thickness of $8 \mathrm{~m}$ spans is considered. In this regard, a simple 2D model, which is basically developed according to material tests for the bridge, is considered to be representative of the second stage analysis according to UIC 778-3. A sophisticated 3D model, which is calibrated and verified according to test results as presented in section 5, is also considered as representative of the third stage analysis. Moreover, a 2D model of the bridge is developed in Ring software, which is designed to calculate the ultimate load-carrying capacity of masonry arch bridges. 


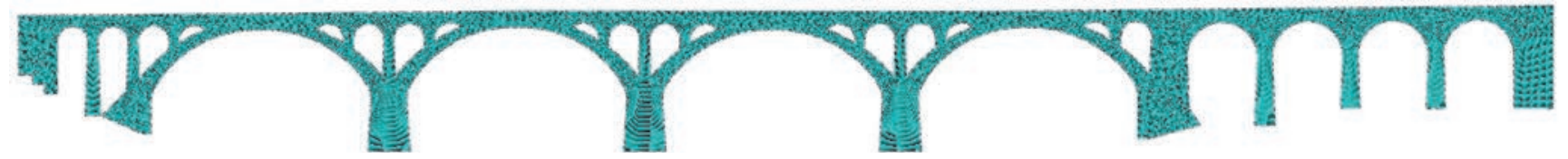

Figure 18. Simple 2D model of the Mianeh Bridge

According to UIC 778-3, partial safety factors of permanent loads, live loads, and material characteristics are 1.35, 1.45, and 2.25, respectively. BD 91/04 takes a partial safety factor of 1.65 for live loads, and 1.35 for permanent loads.

Simple 2D model, presented in Figure 18, was developed in Abaqus based on material test results, and it simplifies elaboration of details such as joints and ballast on the bridge. 4-node elements were used to develop this model. On the other hand, the calibrated 3D F.E. model, which was developed and calibrated according to test results, is related to all structural details of the bridge and it takes advantage of accurate characteristics of materials. The non-linear modelling of materials is conducted in the 3D model as well, which allows for non-linear model assessment and occurrence of plastic hinges in the model. The stone damage plasticity model is used as the constitutive model of stone material of the bridge. Figure 19 shows the stress-strain diagram of masonry material [22]. Ring has also been recommended by UIC 778-3 for determining the ultimate load carrying capacity of masonry arch bridges. Ring integrates the rigid block limit analysis method, in which single and multi-ring arches are modelled as in-plane structures and arches as assemblages of rigid blocks. Through such modelling, it is possible to determine the collapse load and collapse mechanism.

It is obvious that a specific load factor must be defined for each possible location of the moving vehicle. Hence the LM71 is applied in the quarter and middle of each span, and the load and mechanism of collapse are determined. The collapse mechanism values calculated via Abaqus and Ring for both span lengths (25 meters and 8 meters) are presented in Figure 20. The corresponding loading factors from Figure 20 are presented in Table 4. It should be noted that the lowest value of the loading factor determined via two and three dimensional models is presented in Table 4, since the minimum value of all possible load factors is the one of interest. Results of assessing the bridge at ULS according to BD 91/04 are presented in Table 5. In Table 5, "P" is the axial force and " $P_{n}$ " is the axial capacity of the section. In the worst scenario, the difference between the results of the two standards is less than $17 \%$.

Since the 3D finite element model is the most comprehensive of all, it is possible to determine under/over estimation of other models compared to the 3D model. Table 6 presents over/under estimation of 2D models and BD91/04 method compared to that of the $3 \mathrm{D}$ model. Based on these results, it could be concluded that the higher the span length, the higher the over/ under estimation of 2D models. However, 2D models could be used for simple bridges with no secondary arches with a great deal of confidence.

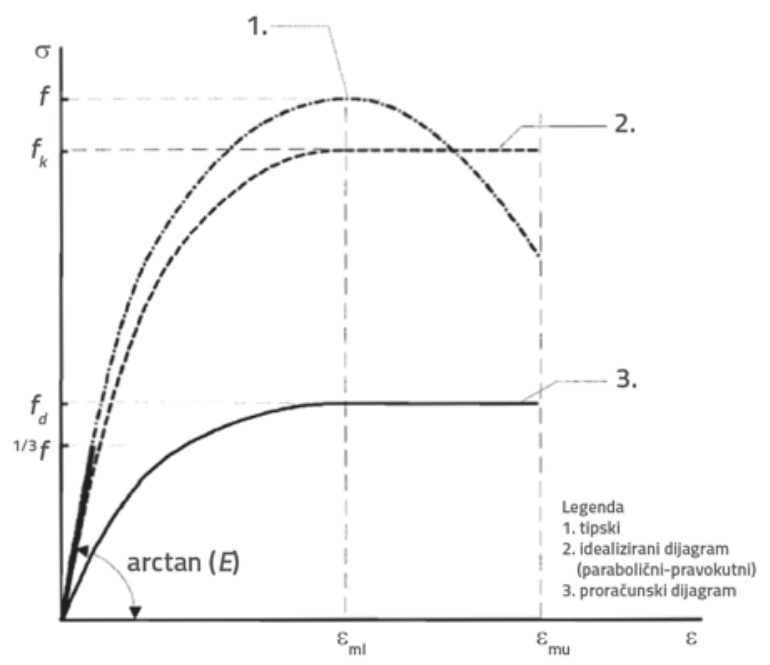

Figure 19. Stress-strain diagram for stone material [22]

Table 4. Ultimate load carrying capacity of $25 \mathrm{~m}$ and $8 \mathrm{~m}$ spans, resulting from application of LM71, as calculated via two and three dimensional models

\begin{tabular}{|c|c|c|c|}
\hline \multirow{2}{*}{ Span length $[\mathrm{m}]$} & Model type & Quarter-Span & Middle-Span \\
\hline \multirow{3}{*}{25} & 3D (Abaqus) & 2.00 & 2.10 \\
\cline { 2 - 4 } & 2D (Abaqus simple model) & 2.30 & 2.50 \\
\cline { 2 - 4 } & 2D (Ring) & 1.57 & 2.30 \\
\hline \multirow{2}{*}{8} & 3D (Abaqus) & 3.90 & 4.50 \\
\cline { 2 - 4 } & 2D (Abaqus simple model) & 4.30 & 4.80 \\
\cline { 2 - 4 } & 2D (Ring) & 4.48 & 4.49 \\
\hline
\end{tabular}




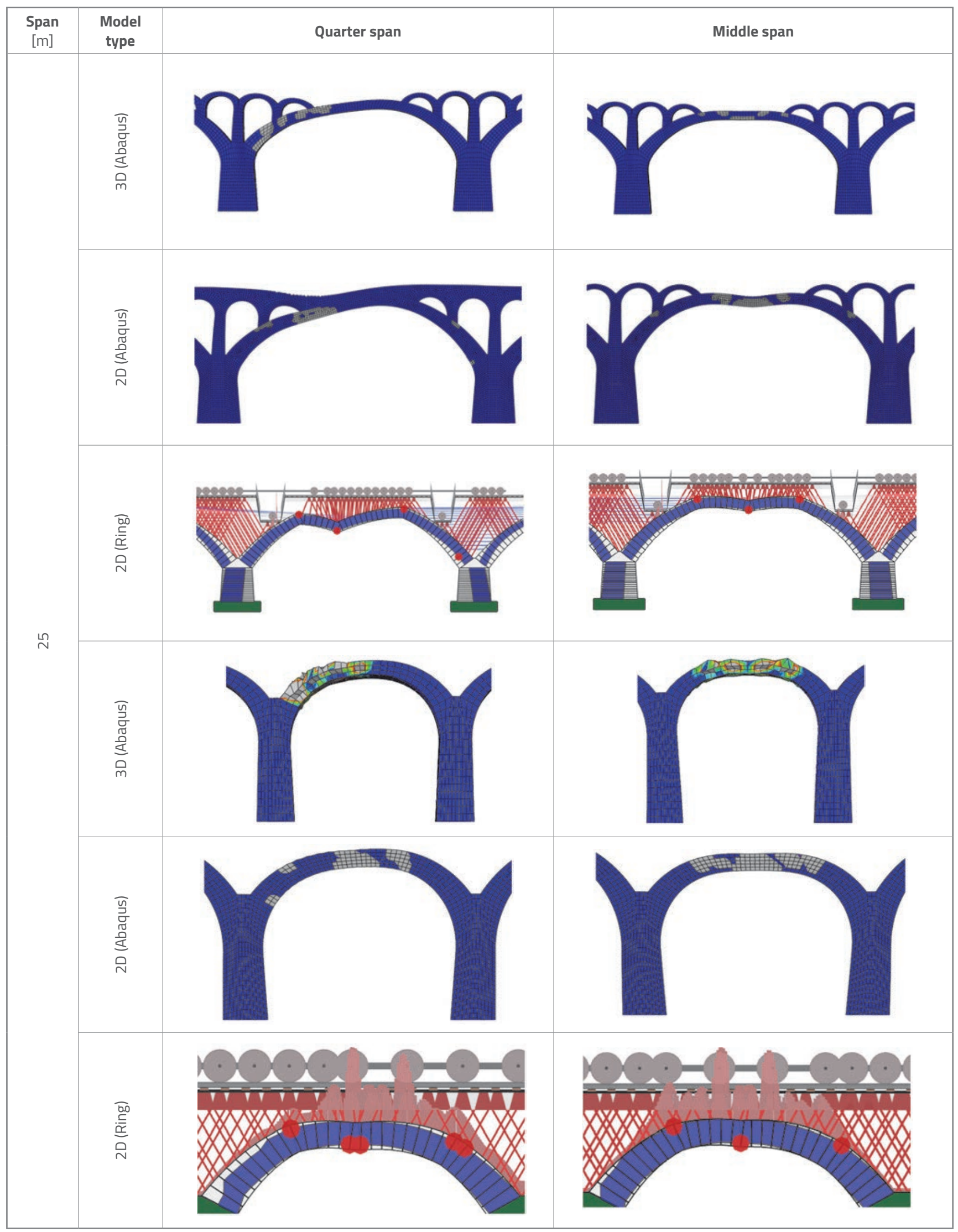

Figure 20. Failure mechanisms for $\mathbf{2 5} \mathrm{m}$ and $8 \mathrm{~m}$ spans, as calculated by two and three dimensional models 
Table 5. Ultimate load carrying capacity of 25 and 8 meters spans for LM71 ("M" is moment and "P" is axial force)

\begin{tabular}{|c|c|c|c|c|c|c|c|}
\hline & Span & $\begin{array}{c}\text { M - moment [Nm] } \\
\text { P - axial force [N] }\end{array}$ & $\mathbf{h}[\mathrm{mm}]$ & e [mm] & $\mathbf{P}[\mathrm{kN}]$ & Pn [kN] & Loading factors \\
\hline \multirow{4}{*}{$25 \mathrm{~m}$} & \multirow{2}{*}{ Middle-Span } & $M=460000$ & \multirow{2}{*}{1100} & \multirow{2}{*}{438.10} & \multirow{2}{*}{105.00} & \multirow{2}{*}{257.83} & \multirow{2}{*}{2.46} \\
\hline & & $P=1050000$ & & & & & \\
\hline & \multirow{2}{*}{ Quarter-Span } & $M=698000$ & \multirow{2}{*}{1350} & \multirow{2}{*}{549.61} & \multirow{2}{*}{127.00} & \multirow{2}{*}{288.91} & \multirow{2}{*}{2.27} \\
\hline & & $P=1270000$ & & & & & \\
\hline \multirow{4}{*}{$8 \mathrm{~m}$} & Middle-Span & $M=120000$ & \multirow{2}{*}{750} & \multirow{2}{*}{305.34} & \multirow{2}{*}{39.30} & \multirow{2}{*}{160.49} & \multirow{2}{*}{4.08} \\
\hline & & $P=393000$ & & & & & \\
\hline & \multirow{2}{*}{ Quarter-Span } & $M=207500$ & \multirow{2}{*}{800} & \multirow{2}{*}{262.66} & \multirow{2}{*}{79.00} & \multirow{2}{*}{316.44} & \multirow{2}{*}{4.01} \\
\hline & & & & & & & \\
\hline
\end{tabular}

Table 6. Comparison of ultimate load carrying capacity of 2D models with that of the detailed 3D model

\begin{tabular}{|c|c|c|c|}
\hline \multirow{2}{*}{ Span length [m] } & Model type & Quarter-Span & Middle-Span \\
\hline \multirow{3}{*}{25} & 3D (Abaqus) & 1.00 & 1.00 \\
\cline { 2 - 4 } & 2D (Abaqus simple model) & 1.15 & 1.19 \\
\cline { 2 - 4 } & 2D (Ring) & 0.79 & 1.09 \\
\hline \multirow{3}{*}{8} & BD 91/04 & 1.13 & 1.17 \\
\cline { 2 - 4 } & 3D (Abaqus) & 1.00 & 1.00 \\
\cline { 2 - 4 } & 2D (Abaqus simple model) & 1.10 & 1.07 \\
\cline { 2 - 4 } & 2D (Ring) & 1.15 & 1.00 \\
\hline
\end{tabular}

\section{Conclusion}

The safety of an old railway masonry arch bridge, which has been in service for more than 70 years, has been assessed by visual inspection and dynamic loading testing, and the possibility of increasing the permitted axle load of the bridge is studied. Visual inspection of the bridge revealed defects such as mortar loss, stone delamination and weathering, and occurrence of leachates at different spots of the bridge. Considering the age of the bridge and its effect on deterioration of masonry, dynamic load tests were carried out on the bridge to gain better understanding about the global response of the material.

Dynamic load tests were carried out using the highest permitted loading scheme of the bridge, consisting of three 120-ton locomotives and five 80-ton freight wagons. The response of the bridge in terms of deflection and vibration following application of three predefined loading schemes were recorded by 15 deflectometers and accelerometers. A 3D finite element model was developed and calibrated using in-situ dynamic load test results.

Dynamic analyses were carried out on the numerical model of the bridge, and critical stresses were calculated for first five spans of the bridge and compared to allowable values specified in BD91-04, with regard to LM71 loading scheme proposed by UIC 776-1 and operational loading schemes of TF1 and TF2. As expected, stresses and eccentricity of the centre of compression due to LM71 are higher than those of TF1 and TF2. The results suggest that compression stresses are not an issue in any of the spans for the increased axle load of 25 tons, while the eccentricity of the centre of compression in middle spans exceeds allowable threshold in all spans, except for the first span. The eccentricity of the centre of compression in the 8-m span is much more critical than that of the $25-\mathrm{m}$ spans, which is by 5 times greater than the allowable threshold. It could be concluded that the bridge, in its current condition, is not capable of withstanding an increased axle load of 25 tons, and that strengthening methods have to be implemented.

The ultimate load carrying capacity of the bridge was determined using a comprehensive $3 \mathrm{D}$ model. The results obtained were then compared to those obtained by two 2D models developed in Abaqus and Ring and the method proposed in BD 91/04. The 2D model in Abaqus presents material test results in which geometrical characteristics of thermal joints and ballast layer are simplified. Taking that the $3 \mathrm{D}$ model is the most accurate of all models, it is possible to determine over/under estimation of 2 D models and BD 91/04 method relative to the 3D model. 
For the 8-m span, Abaqus and Ring 2D models overestimate the load carrying capacity of the bridge by $10 \%$ and $15 \%$, respectively. The BD 91/04 method underestimates the load carrying capacity by $8 \%$. For the $25-\mathrm{m}$ span, the Abaqus 2D model overestimates the load carrying capacity by $15 \%$, while the $2 \mathrm{D}$ Ring model underestimates this capacity by $21 \%$. The BD $91 / 04$ method overestimates the load carrying capacity by $13 \%$. Since the 3D modelling is relatively time consuming, and taking into account the fact that the over/under estimation of the load carrying capacity by both $2 \mathrm{D}$ models does not exceed $21 \%$, the application of 2D models for ultimate load carrying capacity assessment of masonry arch bridges is considered advisable.

\section{Acknowledgment}

The authors would like to thank for the financial support of the Iranian Railway Organization, as provided under the grant number 94-15388, and for the support of the Industrial Cooperation Office of the Iran University of Science and Technology.

\section{REFERENCES}

[1] UIC: UIC masonry arch bridges, Assessment, reliability and maintenance of masonry arch bridges, State of the Art Study, 2004.

[2] Caro, J., Catalan, R.O.: Catalogue of damages for masonry arch bridges, UIC, 2008.

[3] McCann, D., Forde, M.C.: Review of NDT Methods in the Assessment of Concrete and Masonry Structures, NDT\&E International, 34 (2001), pp. 71-84, https://doi.org/10.1016/ S0963-8695(00)00032-3

[4] Savor, Z., Novak, M.: Procedures for reliability assessment of existing bridges, GRADEVINAR, 67 (2015) 6, pp. 557-572.

[5] Kusar, M., Selih, J.: Analysis of bridge condition on State Network in Slovenia, GRADEVINAR, 66 (2014) 9, pp. 811-822.

[6] Tenzera, D., Puz, G., Radic, J.: Visual inspection in evaluation of bridge condition, GRADEVINAR, 64 (2012) 9, pp. 717-726.

[7] Department of transport, Design Manual for Roads and Bridges, The Assessment of highway bridges and structures, London, UK, 3 (1997) 4.

[8] Havey, W.: Application of the Mechanism Analysis to Masonry Arches", ASCE Journal of Structural Engineering, 66 (1988) 5, pp. 77-84.

[9] Clemente, P., Occhiuzzi, A., Railthel, A.: Limit behavior of stone arch bridges, ASCE Journal of Structural Engineering, 121 (1995) 7, pp. 1045-50.

[10] Felice, G.: Assessment of the load-carrying capacity of multispan masonry arch bridges using fibre beam elements, Journal of Engineering Structures, 31 (2009), pp. 1634-1647, https://doi. org/10.1016/j.engstruct.2009.02.022

[11] Prentice, D.J., Ponniah, D.: Testing of Multi-Span Model of Masonry Arch Bridges", In: Proceeding Centenary Year Bridge Conference, Cardiff (UK), Elsevier Science, pp 169-174, 1994.

[12] Cancelliere, I., Imbimbo, M., Sacco E.: Experimental tests and numerical modelling of reinforced masonry arches, Journal of Engineering structures, 32 (2010), pp. 776-792.

[13] Ataei, S., Tajalli, M., Miri, A.: Assessment of load carrying capacity and fatigue life expectancy of a monumental masonry arch bridge by field load testing: A case study of Veresk, Journal of Structural Engineering and Mechanics, 59 (2016), pp. 703-718, https://doi. org/10.12989/sem.2016.59.4.703
[14] Chandra, J.M., Ramaswamy, A., Manohar, C.S.: Safety Assessment of a Masonry Arch Bridge: Filed Testing and Simulations, ASCE Journal of Bridge Engineering, 18 (2013), pp. 162-171, https://doi. org/10.1061/(ASCE)BE.1943-5592.0000338

[15] Marefat, M., Ghahremani, E., Ataei, S.: Load Test of a Plain Concrete Arch Railway Bridge of 20-m Span, Journal of Construction and Building Materials, 18 (2004), pp. 661-667, https://doi. org/10.1016/j.conbuildmat.2004.04.025

[16] Oliveira, D., Lourenco, P., Lemos, C.: Geometric Issues and Ultimate Load Capacity of Masonry Arch Bridges from the Northwest Iberian Peninsula, Journal of Engineering Structures, 32 (2010), pp. 3955-3965, https://doi.org/10.1016/j.engstruct.2010.09.006

[17] Caglayan, B.O., Ozakgul, K., Tezer, O.: Assessment of a Concrete Arch Bridge Using Static and Dynamic Load Test, Journal of Structural Engineering and Mechanics, 41 (2012) 1, pp. 83-94.

[18] Brencich, A., Sabia, D.: Experimental identification of a multispan masonry bridge: The Tanaro Bridge, Journal of Construction and Building Material, 22 (2007), pp. 2087-2099, https://doi. org/10.1016/j.conbuildmat.2007.07.031

[19] Radnic, J., Harapin, A., Smilovic, M., Grgic, N., Glibic, M.: Static and dynamic analysis of the old stone bridge in Mostar, GRADEVINAR, 64 (2012) 8, pp. 655- 665.

[20] UIC, UIC 778-3, 2nd Edition, Recommendations for the Inspection, Assessment and Maintenance of Masonry Arch Bridges, 2011.

[21] Material tests report of Mianeh Railway Bridge, Nasran Group, 2007.

[22] EN 1996-1-1: Design of Masonry Structures, 2005.

[23] Code BD 91/04: Design Manual for Roads and Bridges, Unreinforced masonry arch bridges

[24] EN 1991-2: Actions on structures -Traffic loads on bridges, 2003.

[25] Audenaert, A., Peremans, H., Reniers, G.: An Analytical Model to Determine the Ultimate Load on Masonry Arch Bridges, Journal of Engineering Mathematics, 59 (2007), pp. 323-336, https://doi. org/10.1007/s10665-006-9129-z 